\title{
Performance Evaluation of Real Estate Sector to Fulfill Urban Housing Demand: A Case Study of Monsurabad Housing Estate Pabna, Bangladesh
}

\author{
Mazed Parvez \\ Bangladesh University of Engineering and Technology \\ Email: parvezpust30@gmail.com
}

\begin{abstract}
Bangladesh is one of the in large part populated countries in the sector. With the urbanization fashion, the populace within the city location is increasing every day. These days the population is about 30 million, and on the 12 months 2040, it has miles anticipated at about two hundred million. With the growing city population, housing calls for in will increase every day. However, the call for will increase the high-quality of urban housing decline. Pleasant residence with a better carrier facility cannot be ensured. Non-public housing gives first-rate city housing, which is needed. The real estate area contributes to quality housing to fulfill city housing demand. Pabna is one of the quickest growing cities in Bangladesh. The city has a populace of about 116305 with this huge populace like different towns of Bangladesh, Pabna cannot provide suitable housing to the city dwellers. Monsurabad housing estate, a real estate corporation placed at Pabna, affords housing facilities to urban dwellers. This observation aimed to determine the contribution of real property zone most of the urban housing and the overall performance of housing facility presents through the real estate region. From this overall performance assessment, a new manner will emerge with the aid of which the private sector contribution to fulfill the city housing demand might be determined and cannot apprehend the fine of housing furnished through the real estate area. This has a look at also consists of some lacking of actual estate quarter and recommends overcoming the missing. Subsequently, the examination could explain how the low- and middle-magnificenceincome level humans may be afforded on the entire real estate.
\end{abstract}

Keyword: Real estate, Performance evaluation, demand analysis, Urban Housing

\section{Introduction}

A house is a shelter for relaxation, protection, comfort, and safety from enemies and climate vagaries. It includes an area for rest, snoozing, cooking, and bathing. By housing, it is supposed not only a trifling form of shelter, but also includes those characteristics of consolation, comfort, and services, which might be crucial for households' emotional and social well-being (Hasan and Kabir, 2002). The real estate area is one of the quickest growing and thrusting sectors in Bangladesh. Infrastructural improvement is quite vital for a rustic to rise as a developed nation and make sure housing centers for its residents (Islam M. S. and Hossain A, 2008).

Like many other developing countries, Bangladesh faces an acute shortage of affordable housing both in the urban and rural areas. The housing situation in Bangladesh has never been satisfactory. The majority of dwelling units are temporary, sub-standard, unsafe, and overcrowded (Reza. F, 2007). The massive increase in populace and shrinkage of land within

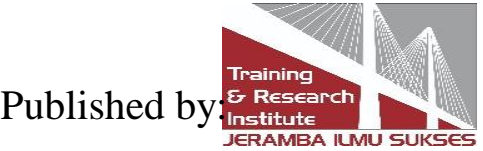


the urban location causes each problem for the middle, higher-middle, and in many cases, for upper-elegance human beings to discover an appropriate region and construct their residence. Those, in flip, make the actual property zone very profitable. The contemporary fashion of the urban boom in Bangladesh is about 5-6\% consistent with annulling. At present, 28\% of Bangladesh's populace lives in urban areas, so that it can be $34 \%$ via the year 2025 (REHAB, 2003).

Bangladesh's government could not meet the demand due to resource scarcity and inefficiency on the government's part. First, human beings take personal initiative to arrange shelter in city areas in maximum instances arranged by using Real estate developers. That means that Bangladesh gets a proper real estate sector for the reason that closing three decades. After the delivery in the 70s and the unexpected increase in the 90s, the sector via this time has 524 rehabs (actual estate and housing affiliation of Bangladesh) registered builders in the marketplace (Islam and Arefin, 2009)

So real estate contributes a lot to the urban housing sector. In Bangladesh, where the population is increasing day by day, it is becoming more changing to provide quality housing. At the individual level, house level and quality increase, but the quality is declining when the term housing comes. Only the government cannot afford too much quality housing for this large population. So real estate comes to play a vital role in meeting the housing demand, especially in urban areas. Real estate is one of the possible industries in Bangladesh. The current style does city growth in Bangladesh is very high. Urbanization is an outcome of both populace increase and migration. As urbanization increases, extra and extra people are becoming town dwellers. The fast growth of population, scarcity of land, and lack of planning and social and environmental troubles in Bangladesh make constructing construction from personal initiative greater unreliable for the low to middle earnings groups.

Nevertheless, non-public developers assemble excessive upward push rental construction with vertical expansion, which requires a small land size for the giant quantity of people. Besides, non-public builders boost building in a planned way that improves the decency. This study evaluates the performance to saturate urban housing demand through the real estate sector and make some recommendations to involve the low-income people in this sector for a better life standard. This study will also determine the housing demand meets by the real estate sector in the urban area and find a better living place. This paper contains three objectives- To analyze the existing urban housing scenario of the study area, make a comprehensive study between real estate areas and surrounding municipality area performance, evaluate the real estate sector's performance to fulfill urban housing demand.

\section{Literature Review}

(Hasan and Kabir, 2002) described the concept of "House." Housing is a broader and multidimensional idea. (REHAB, 2012) helps to understand the present real estate scenario and housing provision in the context of Bangladesh. (Ahmed. R. U, and Rasel. A. 2013) understand the real estate housing pattern and future housing forecasting. Real estate is one 
of the maximum appealing sectors of investment now in Bangladesh. Speedy urbanization has emerged as an acute hassle for the country (Barua et al., 2010).

Real estate development, or assets development, is a multifaceted commercial enterprise, encompassing sports that range from the upkeep and release of present homes to the purchase of raw land and the sale of improved land or parcels to others. Builders are the sports coordinators, converting thoughts on paper into real property (Frej and Peiser, 2003).

Real estate is one of the most recent Bangladesh sectors, specifically out of doors, the capital town Dhaka where this commercial enterprise started in 1970. Currently, this region has got attention due to the increasing extent of urbanization. In Bangladesh, 25 consistent with cent of the population (some 35 million people) now stay in urban areas; this proportion will be 34 consistent with cent (seventy-five million) by the year 2015 (Alam \& Rahman, 2015).

Real Estate Development and Management Act, 2010 recommends mandatory enlistment of developers to do business, a penalty in violating approved design of the building, fixed duration of housing delivery, finalization of the deed, etc. For the development and progress of the real estate sector. According to standard, community facilities, construction of buildings, conservation of geological character of the site, and restriction on the land development for housing in the earthquake-prone area are suggested in the Private Residential Land Development Act, 2004. Stimulation of the production and availability of conventional materials, promotion of proven technology and building materials, provision of financial assistance, strengthening existing Research \& Development in the housing sector, and review of existing building laws and regulations in the light of the National Building Code are accentuated in the National Housing Policy, 1993 (Rahman, 2009).

\section{Research Method}

\subsection{Study Area Profile}

Pabna Municipality is one of the oldest Municipalities in Bangladesh, and it was established in 1876. In 1868 Pabna Town Committee was established before the Pabna Paurashava establishment (Parvez, 2020a). Pabna Paurashava was upgraded to 'A' Category Paurashava in 1989. It is situated at $161 \mathrm{~km}$ North-West of Dhaka city and $110 \mathrm{~km}$ East of Rajshahi city. The area of the Paurashava is about 16sq km, and its population is 1, 27,319. According to the Bangladesh Population Census 2001, the population of the Paurashava is 116,305 , including 60667 (52.16\%) male and 55639 (47.84\%) female population. According to a field survey conducted by the Socioeconomic Survey Team under UGIIP (Parvez \& Islam, 2020). The population of the Paurashava is $1,17,633$, including 61,377 (52.18\%) male and 56,256 (47.82\%) female population. The total no. of households is 23840 . The average literacy rate in the Paurashava area is $72.93 \%$ (Parvez, 2020b). Formal housing projects like traditional site and services schemes can only be undertaken when there is a demand for serviced plots. There is a sufficient number of buyers ready to have plots at a price fixed by different Development Authorities, which are the only public sector housing developer in the city. Paurashava is not interested in developing the housing estate project (MIDP, 2018).

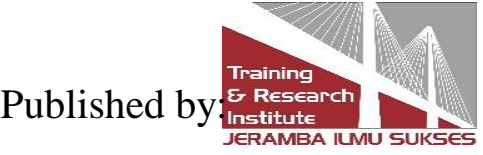


Monsurabad Housing Estate, housing project-1, is located at word no.6, Pabna Paurashava, 83 arches of the total area. The area's current population is 4000 , with a total of 250 plots being developed at the housing estate with 925 households (Monsurabad Authority, 2018).
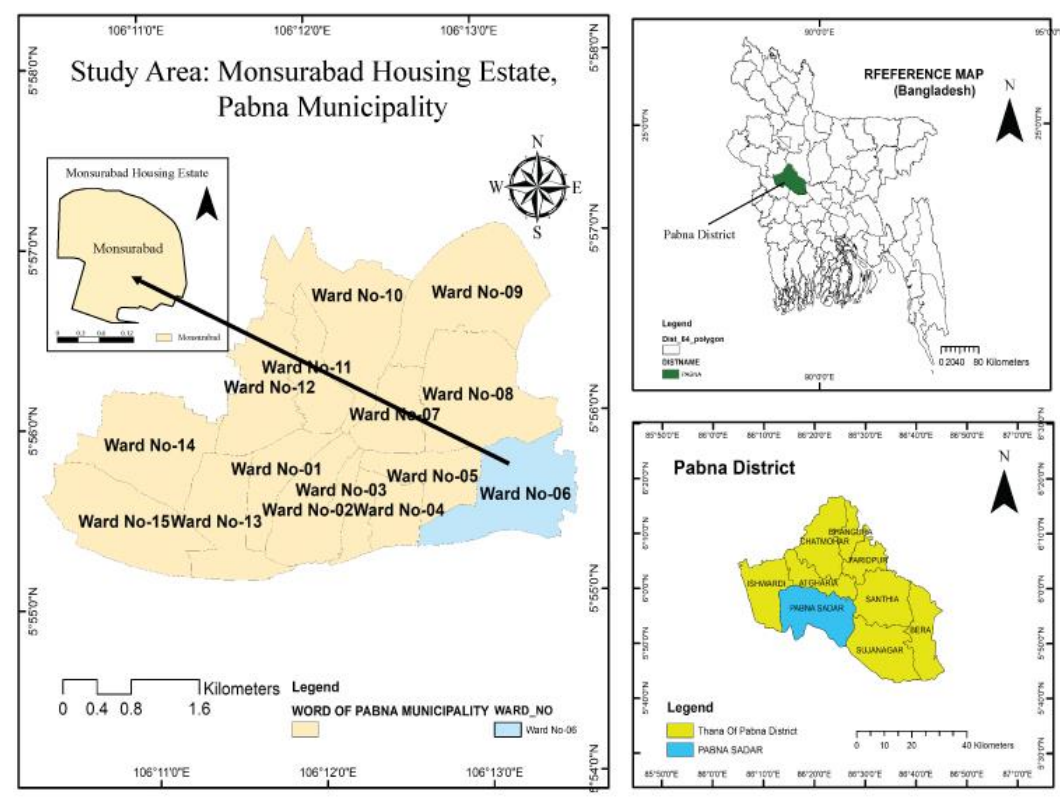

Figure 1. Study area Monsurabad Housing Estate, Pabna, Bangladesh

\subsection{Model Analysis}

"Performance evaluation of real estate sector to fulfill the urban housing demand: a case study of Monsurabad housing estate, Pabna Bangladesh" evolves thru acute overall performance contrast of urban housing demand and makes a competition between real property and other urban vicinity and prescribes the policy makers to contain more in real estate area to meet city housing problems. In the theoretical framework, two strategies are used, as one of them is Literature review and another is a Legislative aspect. In literature evaluate part; a number of reports, books, journals and posted thesis are gone through for clearing number standards such as real estate, house, housing, utility services, migration etc. On the different hand, in legislative component part, a range of governmental policies and policies to enhance and promote the real property quarter and additionally worried about the service standards and a number of policies to encourage the humans to realize the importance of such issue.

The authors used the following equation to determine the Sample size.

$$
n=\frac{z^{2} \rho q N}{(N-1) e^{2}+z^{2} \rho q}
$$

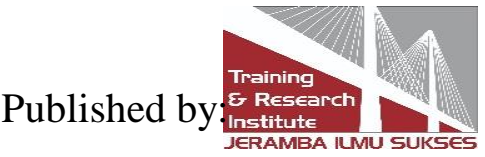


Where $\mathrm{n}$ is the sample size, $\mathrm{Z}$ is the value of the standard deviation at $95 \%$ confidence level (1.96), $\mathrm{p}$ is the sample proportion, $\mathrm{q}$ is equal to $(1-\mathrm{p})$, e is the acceptable margin of error (0.05), $\mathrm{N}$ is the number of households (Kobra et al., 2018). Here the total number of Households of the Monsurabad Housing Estate is 4500. So, $\mathrm{N}=4500$. The sample proportion $\mathrm{p}$ is 0.10 . So, From the equation, the sample size is determined $\mathrm{n}=95$.

Data needs potential figuring out extraordinary data which are indispensable to attain the objectives of the study. Data needs can be classified into the following two groups, such as Primary data needs and Secondary data needs. To conduct this study various secondary data is required. Secondary data needs are as: Existing housing delivery system, supply, average housing size and the average cost of the housing unit of Monsurabad housing estate along with surrounding Pabna municipality area, House rent and household size, The land value of the Real estate and other area and surrounding municipality area. After the assessment of data needs, data are collected from various sources. For this study, necessary data and information were collected from various secondary sources, such as: The objective of this research work is to evaluate the performance of the Real Estate sector to fulfill the urban housing demand will be collected from relevant books, Journals, and website. Urbanization, migration and supply and demand of housing are closely interlinked to each other. Data on migration and housing supply will be collected from various reports of Pabna municipality. The condition and performances of the real estate sector of Pabna municipality area will identify from relevant study and project conducted by Pabna municipality and Real estate. To evaluate the performance of urban housing demand by real estate sector of Pabna municipality area information's of associated real estate areas will be collected from their offices. Data collected from the above-mentioned sources were then recorded, analyzed and presented in both graphical and tabular forms. Standard micro-computer package like SPSS, MS Word, MS Excel for Windows were used for data analysis. In two steps the performance of real estate sector to fulfill the urban housing demand will be carried out two steps. At the first step a comparison will be shown between the real estate housing and the municipality housing. This comparison will show the performance of the real estate that how this sector housing performs. For demand analysis the following method is used to calculate the Housing demand comparison:

$\mathrm{H}=\mathrm{P} / \mathrm{S}$

(P) Is divided by the forecasted average household size $(\mathrm{S})$ to produce the forecasted number of household $(\mathrm{H})$. This is the simplest and widely used technique to forecast the housing need. This method estimates the forecasted household number (Hasan and Kabir, 2002).

\section{Finding and Discussion}

\subsection{Present condition assessment}

\subsubsection{Type of occupation of the respondent}

From the study, it is being clearly seen that most of the respondent respectively $40 \%$ and $40 \%$ are involving at service and business. On the other hand, in the surrounding municipality

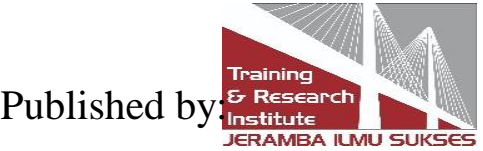


area $50 \%$ people are involved in services and $27 \%$ at business. But in the surrounding area, a significant number of people (total 18\%) are involved in another profession.

\subsubsection{Type of housing construction}

Mainly three types of housing are being seen at urban area. The types are Pucca Building, Semi-pucca, and Kutcha. The two areas building type is given below:

Table 1. Type of Housing Construction in Pabna Paurashava Area

\begin{tabular}{|c|c|}
\hline Type of constriction & Percentage \\
\hline Semi-pucca & 14.0 \\
\hline Pucca Building & 86.0 \\
\hline Total & 100.0 \\
\hline
\end{tabular}

Source: Pabna Paurashava, 2007

Table 2. Type of Housing Construction in Monsurabad area

\begin{tabular}{|l|l|l|}
\hline \multirow{2}{*}{$\begin{array}{l}\text { Type of } \\
\text { Construction }\end{array}$} & \multicolumn{2}{|l|}{ Pabna Paurashava Area } \\
\cline { 2 - 3 } & No. & $\%$ \\
\hline Pucca Building & 7020 & 29.44 \\
\hline Semi-pucca & 13033 & 54.66 \\
\hline Kutcha & 2787 & 11.69 \\
\hline Total & 23840 & 100.00 \\
\hline
\end{tabular}

Source: Field survey, 2020

\subsubsection{Land information}

At the municipality area, most of the plots are 2.5-5 Katha as well as the real estate area. As newly developed real estate Monsurabad housing estate is keener to sell small plot and at the municipality area most dwellers are native, so the plot size is also in small number. But at the surrounding municipality area most lands were purchased long ago. So, the plot size and price are different in two areas. Among the study between two areas, it is being seen that at below 30000-taka income level 30\% people purchase 2.5-5 Katha of land. But at the surrounding municipality area the percentage is about 78. That means in real estate area people are not preferable to purchase a low amount of land. At an income level of 30000-

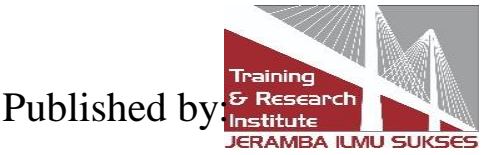


40000 taka at real estate, the purchased land amount is $58 \%$ where at municipality area the amount is below $20 \%$. But at 75000 or over income level the purchased and amount is below $10 \%$. That shows people at real estate area is more preferable of purchasing land of 6-8 Katha at below 30000-taka income level but at surrounding municipality area people likely to purchase the 2.5-5 Katha land at the same income level. For 6-8 Kathaland, $40 \%$ real estate area respondent has more tendencies to purchase at an income level of below 30000 takas. But the surrounding municipality area $76 \%$ of respondent at below 30000-taka range purchase 6-8 Katha land. For 9-12 Katha of land at real estate area 79\% of the respondent who has an income level between 60000-75000 purchases most. But at the surrounding municipality area below 30000 takas and 30000-45000-taka income level respondent purchase 9-12 Katha of land because most of the land was purchased 20-30 years ago. For 13-20 Katha of land at real estate area $100 \%$ of the land is owned by income level of below 30000-taka respondent and at surrounding municipality area equally, 56\% was shared by below 30000 taka and 30000-45000-taka respondent. This also happens because the lands were purchased long ago.

Figure 1. Plot size at the Residential area.

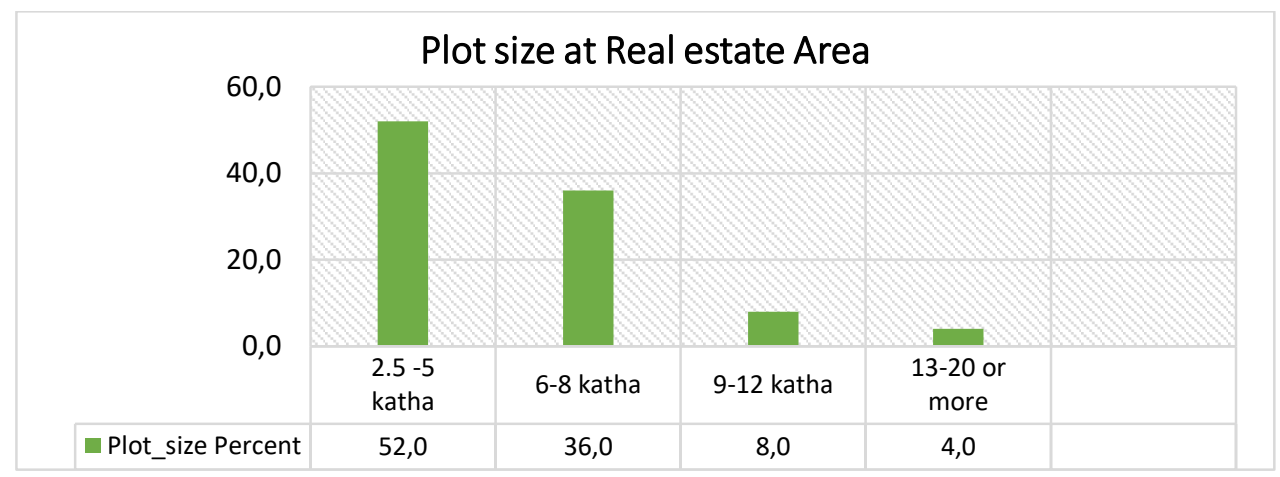

Source: Field Survey, 2020

Figure 2. Plot size at municipality area

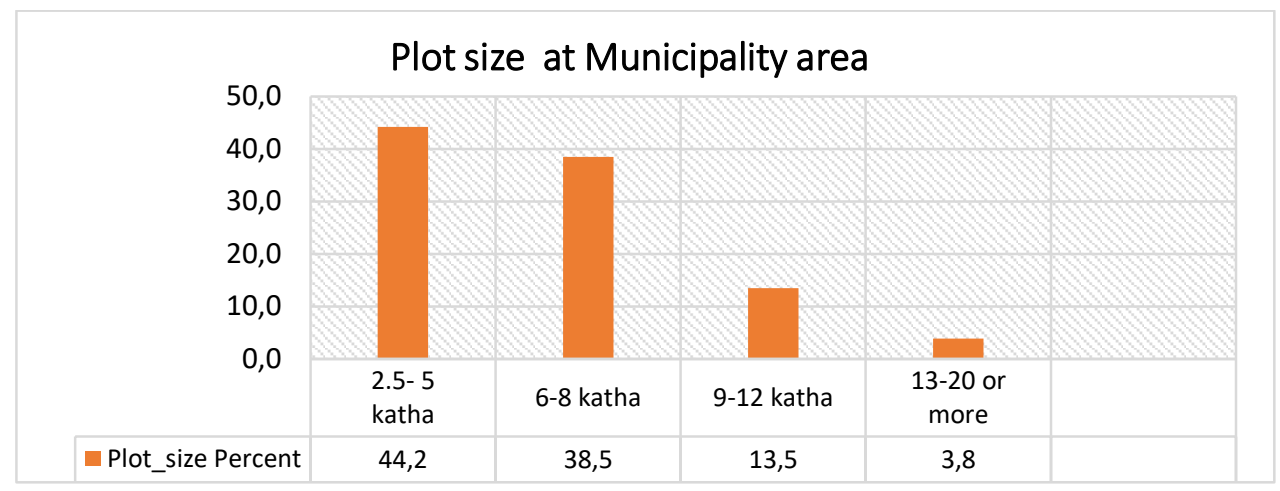

Source: Field Survey, 2020

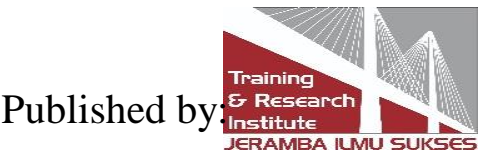




\subsubsection{Price analysis}

There is a huge difference between the present and past price among the real estate area. At the real estate area now a day's present value of land per square feet is nowadays is mostly 1100 and 1500 taka mostly at 14\% each which was in past on average 600 takas to 700 takas. That means the value of the landin the residential area is being doubled in value now a days. But in the municipality area, most $25 \%$ land is in the value of 890 takas per square feet which was in past on an average 300to 400 taka per square feet. Here also the land value increases

\begin{tabular}{|c|c|c|c|c|c|c|c|}
\hline \multicolumn{4}{|c|}{ Real estate } & \multicolumn{4}{|c|}{ Municipality area } \\
\hline \multicolumn{2}{|c|}{$\begin{array}{l}\text { value (per square } \\
\text { feet) area during } \\
\text { purchasing }\end{array}$} & \multicolumn{2}{|c|}{$\begin{array}{l}\text { Value (per square } \\
\text { feet) at present days. }\end{array}$} & \multicolumn{2}{|c|}{$\begin{array}{l}\text { value (per square } \\
\text { feet) area during } \\
\text { purchasing }\end{array}$} & \multicolumn{2}{|c|}{$\begin{array}{l}\text { Value (per square feet) } \\
\text { at present days. }\end{array}$} \\
\hline $\begin{array}{l}\text { Piece in } \\
\text { Taka }\end{array}$ & $\%$ & $\begin{array}{l}\text { Piece in } \\
\text { Taka }\end{array}$ & $\%$ & $\begin{array}{l}\text { Piece in } \\
\text { Taka }\end{array}$ & $\%$ & $\begin{array}{l}\text { Piece in } \\
\text { Taka }\end{array}$ & $\%$ \\
\hline $100-250$ & 68 & $100-250$ & 12 & $100-500$ & 63 & $100-500$ & 11 \\
\hline $250-500$ & 18 & $250-500$ & 21 & $500-1000$ & 25 & $500-1000$ & 42 \\
\hline $500-750$ & 12 & $500-750$ & 42 & $\begin{array}{l}1000- \\
1500\end{array}$ & 08 & $1000-1500$ & 29 \\
\hline \multirow[t]{2}{*}{$\begin{array}{l}750- \\
1000\end{array}$} & 02 & $750-1000$ & 19 & $\begin{array}{l}1500- \\
2000\end{array}$ & 04 & $1500-2000$ & 12 \\
\hline & & Above 2000 & 12 & & & $\begin{array}{l}\text { Above } \\
2000\end{array}$ & 6 \\
\hline
\end{tabular}

but the real estate land value is far better than the other municipality area. Because of more service facilities, the value is high in the real estate area.

Table 3. Competitive piece analysis

Source: Field Survey, 2020

\subsubsection{Reasons behind to choose this plot for purchase}

There is certainly a cause to choose a plot to live, whether it may be size or location, good service facilities or low price of land. From the study, it can clearly see that in the real estate area most dwellers chose a plot because of better service facilities and size and location. Monsurabad is situated near to the terminal which makes a very easy access to the area.

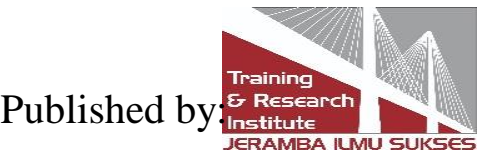


Figure 3. Reasons to choose this plot between real estate and municipality area
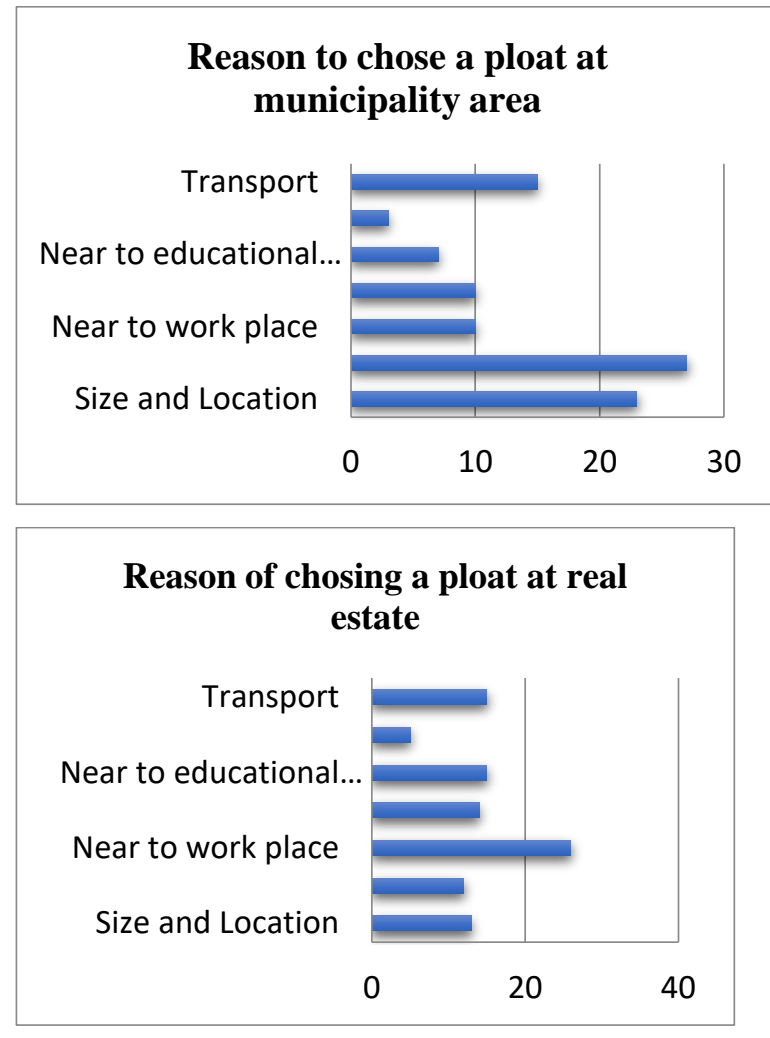

Source: Field Survey, 2020

\subsubsection{Duration of living}

From the analysis, it is clearly seen that a real estate area $48 \%$ people are living at a period of fewer than 5 years and $32 \%$ of people live at a time period of 5-10 years. On the other area, $57.7 \%$ of people live at a time period of more than 20 years and $25 \%$ respondent live 10-20 years. From this, it can be said more people are coming at real estate area rather than the surrounding municipality area. For more service facilities and better road network, more people are coming at the real estate area.

\subsubsection{Rent Rate of Household}

The housing rent results to find out the income group of living. Rent of real estate shows that most of the dwellers have to pay 4500 to as rent. 16\% of dwellers have to pay that rent, also 7.5\% dwellers have to pay 3000 and 5000 taka respectively. But at the surrounding municipality area, 7\% dwellers have to pay 2000 taka and also 5\% of people pay 5000 takas. But a significant thing is that most variety is seen at municipality area in the range of rent starts from 1500 taka to 5000 takas. That means a people with different income level live at the municipality area but at the residential area not too much variable at living standards.

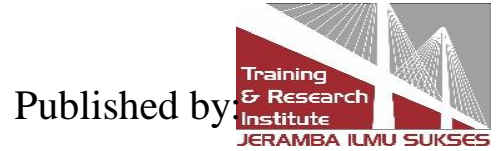




\subsection{Problems analysis}

Problems among two areas show the better living place. The problems between the two areas are divided into (a) Health regarding problems (b) Crime percentage (c) Water logging

\begin{tabular}{|c|c|}
\hline \multicolumn{2}{|c|}{ Health problem at real estate area } \\
\hline no problem & 82,0 \\
\hline Fever & 4,0 \\
\hline Respiratory & 2,0 \\
\hline Dizziness & 4,0 \\
\hline Astama & 4,0 \\
\hline Loss of hearing & 4,0 \\
\hline \multicolumn{2}{|c|}{ Health Problem at municipality area } \\
\hline No problem & 26,9 \\
\hline Fever & 9,6 \\
\hline Respiratory & 11,5 \\
\hline Dizziness & 11,5 \\
\hline Astama & 9,6 \\
\hline Hypertension & 21,2 \\
\hline Loss of hearing & 9,6 \\
\hline
\end{tabular}

Source: Field Survey, 2020

Figure 4. Health-related problems between real estate and municipality area

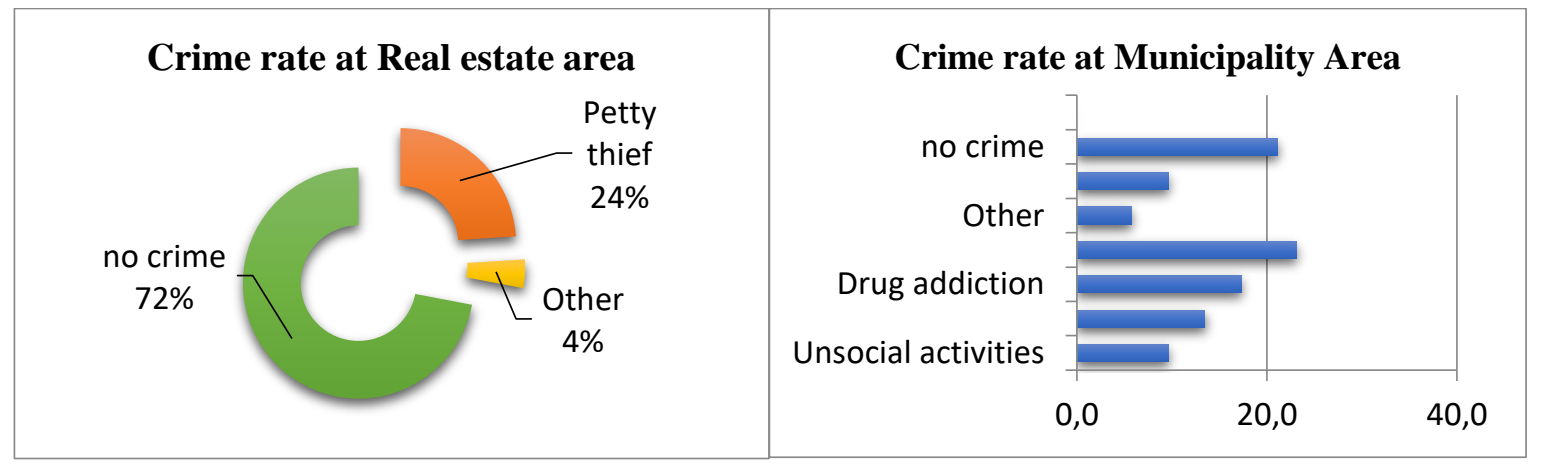

Source: Field Survey, 2020

Figure 5: Crime-related problems between real estate and municipality area

At real estate area $82 \%$ people respond as there are no problems regarding health issues. Very few people mentioned some problems. At the surrounding municipal area $27 \%$ people express that there are no problems in that area. But rest of the people mentioned that there

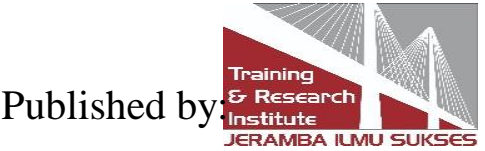


are problems in the area. At real estate area only, some problems are seen in a small percentage but at the surrounding municipality area problems are seen in a large percentage like $21 \%$ respondent faces hypertension, $11 \%$ respondent faces dizziness and so on. So, the analysis shows that the real estate area respondent faces fewer problems rather than the surrounding municipality area. $70 \%$ of dwellers in the real estate area express that there are no problems regarding crime at the real estate area. Only partly thief problem is available at the real estate at the real estate area, but at the residential area only $20 \%$ of people express that there are no problems are in that area likes: partly thief, smoking, unsocial activities are happening at the surrounding municipal area.

Water logging and noise pollution

Table 4. Competitive problem analysis

\begin{tabular}{|c|c|c|c|c|c|}
\hline \multicolumn{3}{|c|}{ Real estate } & \multicolumn{3}{|c|}{ Municipality area } \\
\hline Problem & Yes & No & Problem & Yes & No \\
\hline Water & & & Water & & \\
\hline logging & $68 \%$ & $32 \%$ & logging & $82 \%$ & $18 \%$ \\
\hline Noise & & & Noise & & \\
\hline Pollution & $22 \%$ & $78 \%$ & Pollution & $70 \%$ & $30 \%$ \\
\hline
\end{tabular}

Source: Field Survey, 2020

\subsection{Utility Service Assessment}

\subsubsection{Electricity Bill}

From the electricity bill at real estate area is seen than most $11 \%$ of dwellers respectively have a bill at an amount of 800,900 and 1000 taka respectively. In the municipality area, $15 \%$ of dwellers give an amount of 1200 taka. The less amount of electricity bill percentage is being seen in the real estate area, starts from 300- 400 takas. In the surrounding municipality area, it starts from 500 takas. Most respondents has a bill on an average of 8001400 taka at real estate area but at the surrounding municipality area the average is 700-1500 taka.

\subsubsection{Water Supply Type}

Mainly at the real estate area, people are depended on sub miscible water supply. $60 \%$ of people depend on it. A little number of dwellers at real estate depends on tube well water supply at $30 \%$. As like as the real estate the surrounding municipality area also has nearly same water supply type been available. $62 \%$ of people depend on the sub miscible water

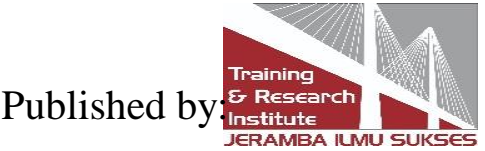


supply. From the study, it is seen that not too much respondents are depended on municipal water supply. A significant thing is being seen that real estate authority isn't providing any kind of water facility to the stakeholders.

A comparative study on service facility assessment between two areas helps to find out the cause to choose dwellers the better living area. From the analysis, it is clearly seen that at water supply $94 \%$ dwellers of real estate are happy with the service and at municipal area $78 \%$ of dwellers are happy. That means water supply is better at real estate area. At electricity also real estate is superior to the municipality area. $100 \%$ satisfaction is at real estate and $80 \%$ at municipality area. A panned way development in the residential area causes better service facilities present at the real estate area. At waste disposal and drainage system also, superiority is present at the estate area. But at a recreational facility, both areas have no facility at all.

\subsubsection{Infrastructural Advantage}

From the data, it is clearly seen that at infrastructural advantages real estate is much superior at good transportation network and fire service but surrounding municipality area is better in an educational institute. From the study, it is clearly seen that all the four sectors: road network, fire service facilities, educational institutions or parking facilities everywhere the real estate is superior to the surrounding municipality area. At real estate area, the road network availability is $95 \%$ where at another area that is $75 \%$. At fire service, the real estate area has $100 \%$ accessibility but surrounding area has $96 \%$ accessibility. Moreover, the educational institutions and parking facility in real estate is respectively $90 \%$ where the surrounding municipality area has $96 \%$ and $75 \%$. The estate authority's action makes the area better than the other surrounding area.

Table 5: Service facility assessment among two areas:

\begin{tabular}{|c|c|c|c|c|}
\hline \multicolumn{3}{|l|}{ Real estate } & \multicolumn{2}{|c|}{ Municipality area } \\
\hline Problem & $\begin{array}{l}\text { Availability } \\
(\%)\end{array}$ & $\begin{array}{l}\text { Non-Availability } \\
(\%)\end{array}$ & $\begin{array}{l}\text { Availability } \\
(\%)\end{array}$ & $\begin{array}{l}\text { Non-Availability } \\
(\%)\end{array}$ \\
\hline Water Supply & 94 & 6 & 78 & 22 \\
\hline Electricity & 100 & 0 & 80 & 20 \\
\hline Drainage & 90 & 10 & 40 & 60 \\
\hline Waste disposal & 92 & 8 & 65 & 35 \\
\hline Recreational & 0 & 0 & 10 & 90 \\
\hline
\end{tabular}

Source: Field Survey, 2020

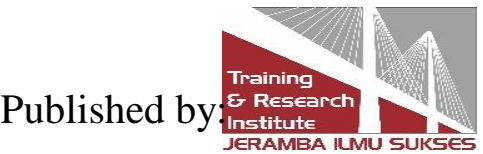




\subsubsection{Accessibility to the land}

Accessibility is a vital issue for land development. Where accessibility is better more dwellers come to live in any area. From the analysis, it is seen that easy access to the land at real estate area is $90 \%$ where at municipality area the percentage is $60 \%$. That means more road network is available at the real estate area more road network is available rather than the surrounding municipality area. At the real estate area, $80 \%$ respondent express that real estate area has better pavement condition. But at surrounding municipality area $60 \%$ respondent express that surrounding municipality area has pavement condition. That means here also real estate has better pavement scenario. Real estate area has less travel time rather than the surrounding municipality area. $95 \%$ respond at real estate respondent express that real estate area has less travel time and $65 \%$ respondent at surrounding respondent express that the surrounding area has less travel time. At the real estate area, $90 \%$ respondent in real estate area agrees that in this area have less travel cost and $60 \%$ respondent in the surrounding area agree that in this area has less travel time. That means here also real estate has better quality rather than the surrounding municipality area.

\subsection{Demand analysis}

Pabna municipality area is a very important area in various factors, like administration, education and also for the population. The present population of Pabna city is 160568 with a growth rate of 1.87 (MIDP, 2008). For this huge population huge amount of housing is necessary. The present household of Pabna Municipality area is 23840 in an area of 3862.196 acres. (MIDP, 2008). This part of the study and analysis helps to identify the household demand of Pabna municipality along with real estate housing demand and contribution of real estate area to meet the household demand of the whole municipality area.

Aggregated Household for Real estate area

\section{$\mathrm{H}=\mathrm{P} / \mathrm{S}$}

Here,

$\mathrm{P}=4000$

$\mathrm{S}=4.32$

$\mathrm{H}=4000 / 4.32=925$ (forecasted number of household)

Value of S (forecasted average household size) is gathered from MIDP,2008.

Aggregated Household for Municipality Area

$\mathrm{H}=\mathrm{P} / \mathrm{S}$

Here,

$\mathrm{P}=160568$

$S=6.25$

Published by $\begin{gathered}\text { E RESearch } \\ \text { lnstitute } \\ \text { JERAMBA IUMU SUKSES }\end{gathered}$ 
$\mathrm{H}=160568 / 6.73=23858$ (forecasted number of household)

Value of S (forecasted average household size) is gathered from Field Survey,2020.

The Forecasted total number of households at Monsurabad Housing estate Area is 925, and the Total Forecasted number of households in the Municipality Area is 25690. Real estate meets 3.87\% Household of Total Housing of Pabna Municipality. The Total Area of Monsurabad Housing estate is 83 acres, and the total housing area of the Pabna Municipality is 3862.196 . So Real estate covers $2.14 \%$ of the total housing area. So, finally, it can be said that from the analysis is that real estate meets $3.87 \%$ of the average household with $2.14 \%$ area of the total Pabna municipality area.

The analysis shows that there is no recreational facility system in the real estate area. Though Monsurabad housing estate does have a proposed recreational park, there is no execution measure being taken till now. For increasing recreational facility there must have a recreational park in the area. So, the park should be established as soon as possible, according to the Private Residential Land Development Act, 2004. The estate authority is bound to provide water supply and electricity at its own cost.

Nevertheless, the analysis shows that no such measure is taken to solve the water supply problem. A large number of people depend on sub miscible water supply and tube well. So real estate authority should focus on providing water supply by its effort. Almost $68 \%$ of real estate dwellers are affected by the waterlogging problem in the Monsurabad area. There is no central drainage system at Monsurabad housing estate. So, the water logging problem exists. The authority should take measures to solve the problem. According to the Private Residential Land Development Act, 2004, the estate authority has to solve the waterlogging problem if it occurs somehow in the project area during construction or after construction. Some partly thief occurrences sometimes happen. Though there are guards for security, even this happens. So, security should be tighter to prevent the problem.

Monsurabad housing estate meets a $3.87 \%$ average household with $2.14 \%$ area of the total Pabna municipality area with the better service facility. So, the Government should provide some more cheap land and develop a private-public partnership so that lot more quality housing will come in the future. With this massive demand for residences in the future, the private Real Estate Sector has plenty of opportunities to play an essential role in enjoyable people's housing wishes. The whole extent of the Real Estate sector has accelerated every 12 months pleasing the city people's housing needs in the remaining few decades. Moreover, contributions to the Government exchequer via Registration Fees, VAT, (AIT), Stamp Duty, Property Handover Tax, etc. has improved each year. In the future, this area has considerable potential to make its extent bigger and, as a consequence, contribute more to the country's broad economy. For this, enough, the Government helps is required. While negotiating with the Government, this can be argued that, as a substitute, tighten the grip to regulate this sector. Suppose the Government takes initiatives to help this region to develop and increase its volume. In that case, this quarter will be able to contribute more no longer solely via generating extra revenue to the Government but also by producing extra employment

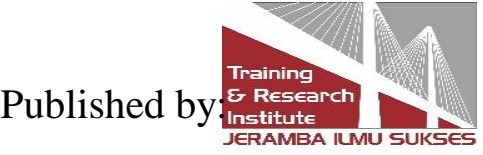


possibilities to the humans and with the aid of gratifying the necessary housing wishes of the people.

\section{Conclusion}

Bangladesh is one of the most populated countries in the world. With the increasing urban, it becomes challenging to provide quality housing to urban dwellers. Nevertheless, the private sector covers the problem related to quality housing. A growing city like Pabna is also covered with the urban housing problem. The real estate provides urban housing to urban dwellers. The real estate sector performance ensuring quality housing demand is shown in this study. Also, the demand which is meeting by the real estate sector to fulfill the urban housing demand is shown. With only $2.8 \%$ urban housing space, $3.6 \%$ of urban housing demand falls by real estate secretor. This study only carries out the scenario of Pabna city but paves a way to determine real estate contribution to Bangladesh's housing. The amount of land in the real estate sector is so little. However, if policymakers give concentration to this situation and provide low-priced land to the real estate sector, more quality housing can be ensured. Furthermore, finally, for quality urban housing development, a public-private partnership between real estate and the government can solve Bangladesh's urban housing problem.

\section{Abbreviations}

REHAB: Real Estate \& Housing Association of Bangladesh; MIDP: Municipality Infrastructure Development Plan; UGIIP: Urban Governance and Infrastructure Improvement Project; AIT: Advance Income Tax.

\section{Conflict Of Interest}

The authors confirm no conflict of interest.

\section{Acknowledgments}

Authors would like to acknowledge the Department of Urban and Regional Planning Pabna University of Science and Technology (PUST). Special thanks go to Md. Sohel Rana, Chairman, Department of Urban and Regional Planning, Pabna University of Science and Technology. Special thanks go to Planner's Research Forum, Pabna University of Science and Technology (PUST).

\section{References}

Ahmed, F., Reaz Uddin, and Rasel Ahammad, S. (2013). Future of Real Estate Business (Ready-made Flat) in Khulna City. International Journal of Scientific and Research Publications, Vol.3. No.12.

Alam, M., and Rahman, M. (2015). Real Estate Business and its Impact on Urban Growth: A Study on Jalma Union, Batiaghata Upazila, Khulna. Journal of Bangladesh Institute of Planners, Vol. 8, pp. 85-92.

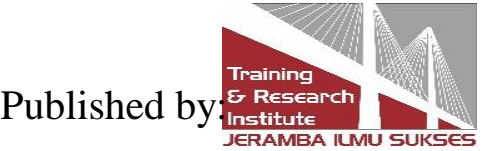


Barua. S, Mridha. A.H.A.M, and Khan. R. (2010). Housing, real estate sector in Bangladesh present status and policies implications. ASA University Review. Vol.4, No.1, pp. 239-253.

Frej A. B \& Peiser, R. B. (2003) "Professional Real Estate Development", Second Edition: The ULI Guide to the Business. Urban Land Institute, pp. 3

Hasan, M. and Kabir, A. 2002. An Introduction to Housing in Bangladesh Khulna: Bangladesh Centre for Human Welfare and Sustainable Development (BCHWSD).

Islam M. S. and Hossain A. 2008, Operations of Bangladesh Housing Industry: An Uncertain Supply Chain Model, The AIUB Journal of Business and Economics (AJBE), Vol.7, No.2, August.

Islam, Md. T., \& Arefin, K. 2009. Real Estate Market in Bangladesh: Development and Current Practice. SSRN Electronic Journal, 1. https://doi.org/10.2139/ssrn.2979250.

MIDP [Municipality Infrastructure Development Plan], 2008. Municipality Infrastructure Development Plan, Pabna. Parvez, M. (2020a). Effectiveness of Participatory Planning for Community Development: A Case Study on Ward No-6 in Pabna Municipality. Electronic Journal of Education, Social Economics and Technology, Vol.1, No.1, pp 1-9. https://doi.org/10.33122/ejeset.v1i1.3

Parvez. M (2020b). Comprehensive Study on Distribution of Public Service Facilities and Their Scantiness by Threshold Population: A Spatial Analysis on Pabna, Bangladesh. Journal of City and Development. 2020, Vol. 2, No.1, pp. 1-6. doi: 10.12691/jcd-2-1-1

Parvez, M., \& Islam, S. (2020). Sites Suitability Analysis of Potential Urban Growth in Pabna Municipality Area in Bangladesh: AHP and Geospatial Approaches. Journal of Geographical Studies, Vol.3, No. 2, pp. 82-92. https://doi.org/10.21523/gcj5.19030204

Rahman, M.A (2009). Addressing the Problems and Prospects of Real Estate Market Dhaka City: A Case Study on Mirpur 2 and 8. Unpublished BURP thesis, Department of Urban and Regional Planning, Jahangirnagar University, Dhaka.

Reza, F. 2007. Real estate development of Dhaka city: major potentials and problems, Unpublished BURP thesis, Department of Urban and Regional Planning, Jahangirnagar University, Dhaka.

REHAB (Real Estate and Housing Association of Bangladesh) 2003. REHAB Housing Fair 2003 (Dhaka, REHAB).

\section{Copyrights}

Copyright for this article is retained by the author(s), with first publication rights granted to the journal.

This is an open-access article distributed under the terms and conditions of the Creative Commons Attribution license (http://creativecommons.org/licenses/by/4.0/)

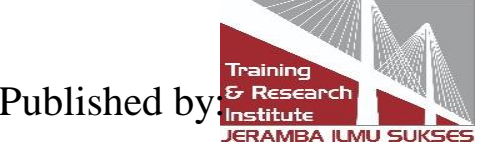

